\title{
KARAKTERISTIK KUALITAS IKAN ASAP YANG DIPROSES MENGGUNAKAN METODE DAN JENIS IKAN BERBEDA
}

\author{
Fronthea Swastawati, Titi Surti, Tri Winarni Agustini, Putut Har Riyadi
}

\begin{abstract}
ABSTRAK: Tujuan penelitian ini adalah mengembangkan IPTEK bagi masyarakat dengan memberikan informasi mengenai kualitas ikan asap yang diproses menggunakan smoking cabinet dan tungku tradisional. Penggunaan smoking cabinet dan tungku tradisional diharapkan dapat menjadi alternatif metode pengasapan yang ramah lingkungan, tidak menimbulkan bahaya karsinogen, serta menghasilkan kualitas ikan asap yang baik. Dalam penelitian ini, menggunakan jenis ikan lele (Clarias batrachus) (L) dan patin (Pangasius pangasius) (P) karena banyak dijumpai di Indonesia dan sering diolah menjadi ikan asap. Sampel ikan diasapi menggunakan smoking cabinet (LSC dan PSC) dan tungku tradisional (LTr dan PTr), kemudian dilakukan analisa mengenai kualitas ikan asap meliputi organoleptik, analisa proksimat (kadar protein, lemak, air, dan abu), pH, kandungan Polycyclic Aromatic Hydrocarbons (PAHs) terutama Benzo ( $\alpha$ ) Pyrene (BaP), senyawa karbonil meliputi phenol, asam organik, dan formaldehid. Rancangan penelitian ini menggunakan pola faktorial $2 \times 2 \times 2$, meliputi perbedaan metode pengasapan dan jenis ikan dengan dua kali ulangan. Hasil penelitian menunjukkan bahwa perbedaan metode pengasapan dan jenis ikan memberikan perbedaan sangat nyata $(P<0,01)$ terhadap nilai proksimat (kadar protein, lemak, air, abu). Kandungan phenol, formaldehid, dan asam organik yang lebih tinggi adalah menggunakan tungku. Sehingga dapat disimpulkan bahwa kedua metode pengasapan dan jenis ikan tersebut dapat diterapkan untuk pengolahan pengasapan ikan meskipun terdapat kecenderungan karakteristik yang spesifik pada produk yang dihasilkan dalam hal kenampakan, bau, tekstur dan rasa.
\end{abstract}

Keywords: metode pengasapan, organoleptik, proksimat, pH, kualitas ikan

\section{PENDAHULUAN}

Kualitas ikan asap merupakan gambaran karakteristik dari produk tersebut yang mempengaruhi akseptabilitas konsumen. Di Indonesia, pengasapan ikan sebagian besar masih bersifat tradisional, belum mempertimbangkan faktor kesehatan dan keamanan pangan. Disamping itu pengasapan tradisional seringkali memberikan dampak negatif terhadap lingkungan, serta timbul kekhawatiran kkonsumen terhadap senyawa karsinogenik dan polusi udara, namun kenyataannya hasil produk tetap digemari oleh masyarakat.

Umumnya, masyarakat pengolah tergolong masyarakat dengan pengetahuan yang kurang, sehingga peralatan pengasapan tidak dilengkapi dengan cerobong asap karena mahalnya biaya pembuatannya, pengasapan menggunakan alat yang sederhana kurang praktis dan tidak produktif. Sehingga perlu dikembangkan teknologi pengasapan yang semi modern dan masyarakat mudah menggunakannya. Pemanfaatan smoking cabinet sebagai alternatif metode pengasapan yang ramah lingkungan sudah saatnya diterapkan di Indonesia.

Penelitian ini bertujuan untuk mengevaluasi kualitas dan kandungan senyawa Benzo $(\alpha)$ Pyrene pada ikan lele dan patin yang diproses menjadi ikan asap menggunakan

Artikel dikirim 26/03/2013, artikel diterima 01/07/2013. Para penulis adalah dari Program Studi Teknologi Hasil Perikanan, Fakultas Perikanan dan IImu Kelautan, Universitas Diponegoro, Semarang. Kontak langsung dengan penulis Fronthea Swastawati (frothea_thp@undip.ac.id).

@2013 Indonesian Food Technologist Community Available online at www.journal.ift.or.id smoking cabinet dan tungku tradisional.

\section{MATERI DAN METODE}

Materi

Penelitian dilakukan dengan menggunakan ikan Lele berukuran panjang $\pm 20 \mathrm{~cm}$, dengan berat rata-rata $\pm 250 \mathrm{~g}$ dan ikan patin berukuran panjang $\pm 25 \mathrm{~cm}$, berat rata-rata \pm 350 g. kedua jenis ikan ini berasal dari Pasar Kobong Semarang. Tempurung kelapa sebanyak 10kg digunakan sebagai bahan bakar pengasapan pada smoking cabinet dan tungku tradisional, dan garam sebagai penambah cita rasa.

\section{Metode}

Penelitian ini dilakukan secara ekperimental dengan menggunakan rancangan pola faktorial $2 \times 2 \times 2$. Terdapat dua faktor dengan masing-masing diberi dua kali ulangan. Faktor pertama adalah perbedaan metode pengasapan smoking cabinet dengan tungku tradisional, faktor kedua adalah perbedaan jenis ikan yaitu ikan lele dan ikan patin. Kedua jenis ikan tersebut direndam dalam larutan garam 5\%, selanjutnya masing-masing ikan diasapi menggunakan metode pengasapan smoking cabinet dan tungku tradisional selama \pm 3 jam.

Prosedur pengujian organoleptik (SNI No. 01-2725.1-2009),

Uji organoleptik merupakan uji mutu suatu bahan dengan bantuan alat indera manusia. Organoleptik ikan asap menggunakan SNI No. 01-2725.1-2009. Nilai score sheet terdiri dari 9 untuk paling baik dan 1 untuk yang terjelek. Kedua uji organoleptik dilakukan oleh 15 orang panelis 
terdidik dari mahasiswa Teknologi Hasil Perikanan Fakultas Perikanan dan Ilmu Kelautan.

Pengujian kadar protein (SNI No. 01-2354.4-2006)

Penentuan kadar protein dilakukan dengan metode Kjeldahl. Pada dasarnya dapat dibagi menjadi tiga tahapan yaitu proses destruksi, destilasi dan titrasi. Dalam proses destruksi sampel dipanaskan dengan $\mathrm{H}_{2} \mathrm{SO}_{4}$ pekat sehingga terurai menjadi unsur-unsurnya. Agar proses lebih cepat digunakan katalisator $\mathrm{Na}_{2} \mathrm{SO}_{4}, \mathrm{CuSO}_{4}$, dan selenium. Proses destruksi selesai bila larutan sudah jernih atau tidak berwarna. Tahap destilasi yaitu amonium sulfat dipecah menjadi amonia dengan penambahan $\mathrm{NaOH}$ sampai alkalis dan dipanaskan. Amonia yang terbentuk ditampung dalam $\mathrm{H}_{3} \mathrm{BO}_{3}$ pekat yang sudah diberi indikator BCG dan methyl red. Jumlah $\mathrm{H}_{3} \mathrm{BO}_{3}$ yang bereaksi dengan amonia dapat diketahui dengan menitrasinya dengan menggunakan $\mathrm{HCl}$ 0,02 M. Akhir titrasi ditandai dengan perubahan warna larutan dari biru tua menjadi merah muda. Perlakuan blanko dilakukan untuk mengetahui nitrogen yang berasal dari reagensia yang digunakan.

\section{Penentuan kadar lemak (SNI No. 01-2354.3-2006)}

Penentuan kadar lemak berdasarkan metode Soxhlet, prinsipnya adalah memisahkan lemak atau minyak dari bahan dengan mengekstraksinya ke dalam pelarut organik. Dalam hal ini digunakan chloroform, lemak yang sudah terekstraksi di dalam labu lemak dialiri gas $\mathrm{N}_{2}$ dengan tujuan untuk menguapkan pelarut organik yang masih terikut di dalam labu lemak.

\section{Penentuan kadar air (SNI No. 01-2354.2-2006)}

Analisa kadar air menggunakan prinsip gravimetri, yang didasarkan dengan penimbangan berat jumlah molekul air yang tidak terikat dalam suatu bahan pangan. Prosedur dilakukan dengan menghilangkan molekul air melalui pemanasan dengan oven vakum pada suhu $95-100^{\circ} \mathrm{C}$ selama 5 jam atau dengan oven tidak vakum pada suhu $105^{\circ} \mathrm{C}$ selama $16-24$ jam. Penentuan berat air dihitung berdasarkan gravimetri dengan selisih berat contoh sebelum dan setelah dikeringkan.

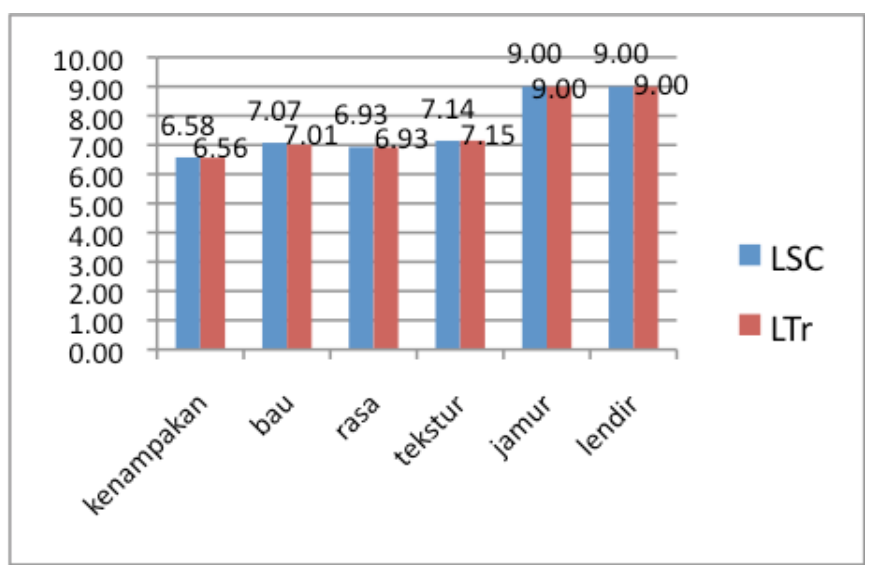

Gambar 1. Nilai organoleptik ikan lele asap
Penentuan kadar abu (SNI No. 01-2354.1-2006)

Kadar abu, dilakukan berdasarkan metode gravimetri yaitu selisih berat sebelum dan setelah diabukan, untuk mengetahui jumlah residu anorganik yang dihasilkan dari pengabuan. Contoh dioksidasi pada suhu $550^{\circ} \mathrm{C}$ dalam tungku pengabuan selama 8 jam atau hingga diperoleh abu berwarna putih, kemudian dihitung berdasarkan gravimetri.

$\mathrm{pH}$ (Manual Procedure)

Sampel dihaluskan, ditimbang senanyak 1 gram dalam gelas piala. Kemudian ditambahkan $10 \mathrm{~mL}$ aquadest dan dilakukan pengadukan. Selanjutnya, sampel dalam wadah diukur $\mathrm{pH}$ nya dengan menggunakan $\mathrm{pH}$ meter yang telah dikalibrasi dengan larutan buffer $\mathrm{pH} 4$ dan buffer $\mathrm{pH} 7$. Nilai $\mathrm{pH}$ diperoleh berdasarkan pembacaan pada $\mathrm{pH}$ meter sampai angka digital menunjukkan angka yang konstan.

\section{Phenol (Metode Folin Ciocalteu)}

Penentuan kadar fenol dilakukan dengan melarutkan $50 \mathrm{mg}$ sampel dalam 2,5 $\mathrm{ml}$ etanol 95\%, kemudian dikocok dengan vorteks. Larutan tersebut disentrifus dengan kecepatan putaran $4000 \mathrm{rpm}$ selama 5 menit. Supernatan diambil sebanyak $1 \mathrm{ml}$ kemudian dicampur dengan $1 \mathrm{ml}$ etanol $95 \%$ dan $5 \mathrm{ml}$ air suling, lalu kemudian dikocok dengan vorteks. Campuran tersebut didiamkan selama 5 menit. Setelah 5 menit larutan ditambahkan dengan $1 \mathrm{ml}$ $\mathrm{Na} 2 \mathrm{CO} 35 \%$, kemudian dikocok dengan vorteks. Setelah itu, larutan tersebut disimpan dalam ruang gelap selama 1 jam, lalu dilakukan pengukuran dengan spektrofotometer pada panjang gelombang $725 \mathrm{~nm}$. Kadar fenol ditentukan berdasarkan persamaan kurva standar. Standar yang digunakan untuk pembuatan kurva standar adalah asam galat. Standar asam galat dibuat dengan konsentrasi 0,25 , 50, 100, dan $200 \mathrm{mg} / \mathrm{L}$.

Formaldehid (AOAC, 1990),

Pengujian formaldehid secara kualitatif dilakukan menggunakan metode AOAC (1990). Prinsip pengujian ini adalah penyerapan warna dengan alat spektrofotometri pada panjang gelombang $415 \mathrm{~nm}$. Pengujian ini menggunakan beberapa tahapan proses penetapan formaldehid dan perhitungan kadar formaldehid.

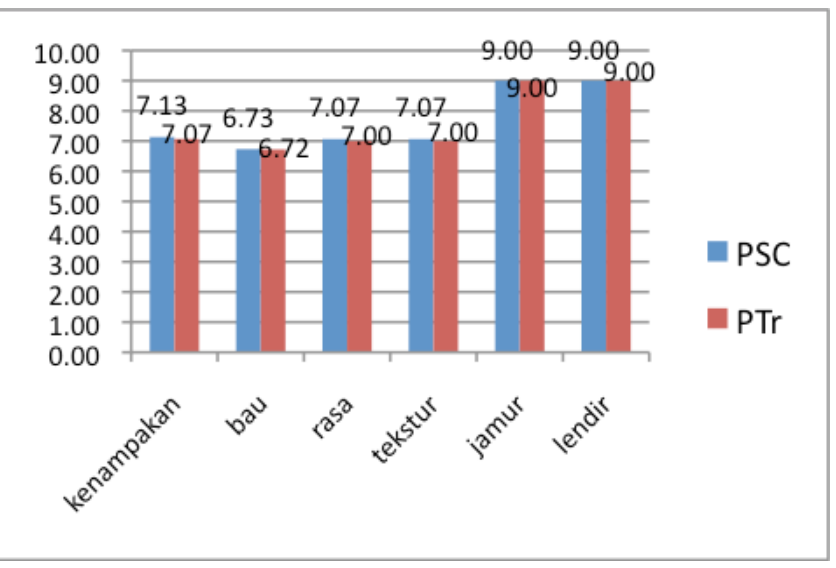

Gambar 2. Nilai organoleptik ikan patin asap 
Tabel 1. Kadar protein ikan asap menggunakan smoking cabinet dan tungku

\begin{tabular}{|c|c|c|c|c|c|c|c|c|}
\hline \multirow[t]{2}{*}{ Ikan } & \multicolumn{2}{|c|}{ Protein } & \multicolumn{2}{|c|}{ Lemak } & \multicolumn{2}{|c|}{ Air } & \multicolumn{2}{|c|}{ Abu } \\
\hline & $\mathrm{SC}(\%)$ & Tungku (\%) & SC (\%) & Tungku (\%) & SC (\%) & Tungku (\%) & SC (\%) & Tungku (\%) \\
\hline Lele & $25,21 \pm 0,04 * *$ & $22,90 \pm 0,10^{* *}$ & $4,85 \pm 0,04 * *$ & $4,24 \pm 0,07^{* *}$ & $62,35 \pm 0,005^{* *}$ & $66,34 \pm 0,05 * *$ & $1,96 \pm 0,03 * *$ & $1,55 \pm 0,03 * *$ \\
\hline Patin & $21,81 \pm 0,07 * *$ & $21,09 \pm 0,06^{* *}$ & $6,77 \pm 0,15^{* *}$ & $5,74 \pm 0,01^{* *}$ & $63,45 \pm 0,28 * * *$ & $61,59 \pm 0,10 * *$ & $2,25 \pm 0,09 * *$ & $1,86 \pm 0,02 * *$ \\
\hline
\end{tabular}

Keterangan: Nilai merupakan rerata dari dua kali ulangan \pm standar deviasi

Data yang dikuti tanda ** perbedaan yang sangat nyata (asymsig $0,000<0,01$ )

Tabel 2. Nilai pH ikan asap yang diolah menggunakan smoking cabinet dan tungku

\begin{tabular}{lrr}
\hline \multicolumn{1}{c}{ Ikan } & Smoking cabinet & Tungku \\
\hline Lele & $6,3 \pm 0,00$ & $6,2 \pm 0,00$ \\
Patin & $5,0 \pm 0,00$ & $5,7 \pm 0,00$ \\
\hline
\end{tabular}

Ket: Rerata dua kali ulangan \pm standar deviasi

\section{Penentuan Benzo ( $\alpha$ ) Pyrene}

10 gr sampel ditambah $10 \mathrm{gr}$ natrium sulfat anhidrat dihomogenisasi dengan $100 \mathrm{ml}$-heptana-eter (4:1) selama 3 menit, kemudian disentrifuge. Residu yang tertinggal ditambahkan kembali dengan $10 \mathrm{gr}$ n-heptana-eter, dihomogenisasi dan disentrifuge kembali. Supernatan kedua dicampur dengan supernatan pertama lalu dimasukkan dalam kolom alumina. Eluen pertama sebanyak $50 \mathrm{ml}$ dibuang kemudian eluen kedua sebanyak $50 \mathrm{ml}$ ditampung dan ditera pada spektrofotometer pada panjang gelombang eksitasi $295 \mathrm{~nm}$ dan emisi $403 \mathrm{~nm}$. Standar benzopyrene digunakan dengan konsentrasi $0-10 \mathrm{mg} / \mathrm{ml}$ untuk kalibrasi (Hadiwiyoto et al., 2000).

\section{HASIL DAN PEMBAHASAN}

\section{Organoleptik ikan asap}

secara umum, ikan lele dan patin asap yang diasapi menggunakan smoking cabinet menunjukkan nilai organoleptik yang lebih tinggi dibandingkan menggunakan tungku (Gambar 1 dan 2).

Ikan lele dan patin asap dengan smoking cabinet, menunjukkan nilai yang tinggi pada kenampakan, bau, rasa, dan tekstur. Perbedaan metode pengasapan dan jenis ikan memberikan perbedaan yang sangat nyata terhadap nilai organoleptik $(P<0,01)$. Hal ini menunjukkan bahwa panelis masih dapat menerima ikan asap menggunakan kedua metode tersebut. Ikan asap yang diasapi menggunakan smoking cabinet memiliki kenampakan yang lebih bersih, warna coklat keemasan yang menarik, serta tekstur yang lebih padat dan kompak dibandingkan ikan asap menggunakan tungku.

Hasil penelitian, ikan manyung asap, yang diolah menggunakan metode pengasapan yang berbeda, tidak memberikan perbedaan yang nyata $(P>0,05)$ terhadap nilai organoleptik. Ini dapat diindikasikan bahwa kedua perlakuan tersebut dapat diterima oleh panelis berdasarkan nilai organoleptik dari ikan manyung asap (Swastawati, 2008).

Kenampakan, bau, warna, dan tekstur dari ikan asap terbentuk akibat dari reaksi gugus karbonil yang terkandung dalam asap bereaksi dengan protein dan lemak dalam ikan. Asap berperan penting dalam pembentukan warna, tekstur, dan rasa. Komponen karbonil utama dalam asap yang berperan penting adalah phenol. Komponen ini, dapat berperan sebagai antioksidan. Warna coklat, dihasilkan dari reaksi phenol dengan oksigen di udara, komponen phenol yang berperan dalam bau dan rasa adalah guaiakol, 4-metil guaiakol, 2,6-dimetoksi phenol. Peran asap dalam hal ini memberikan pengaruh terhadap nilai organoleptik, disebabkan oleh reaksi dari asam, phenol, dan kandungan lainnya dalam asap dengan lemak, protein dan karbohidrat (Cardinal et al., 2006; Swastawati, 2008; Swastawati., et al., 2007).

\section{Analisa Proksimat}

Kualitas ikan asap, antara lain dapat dilihat dari kandungan proksimat, meliputi protein, lemak, ait, dan abu. Analisa proksimat ikan lele dan patin asap yang diolah menggunakan smoking cabinet dan tungku tradisional dapat dilihat pada Tabel 1.

\section{Kadar Protein}

Penggunaan metode pengasapan dan jenis ikan yang berbeda, memberikan perbedaan yang sangat nyata terhadap nilai kadar protein ikan asap $(P<0,01)$. Dapat dilihat dalam tabel 1, nilai kadar protein yang tinggi adalah ikan asap yang menggunakan metode smoking cabinet. Sedangkan berdasarkan jenis ikan, ikan lele asap memiliki nilai protein yang lebih tinggi dibandingkan dengan ikan patin asap. Berdasarkan penelitian dari Ekpenyong et al., (2012), kandungan protein pada african catfish (Clarias gariepenus) asap menggunakan smoking kiln sebesar 10,95 \pm 0,03 .

Perubahan nilai protein ikan, disebabkan oleh adanya proses pengolahan terutama menggunakan panas. Kadar protein dapat menurun karena adanya proses pengolahan, dengan terjadinya denaturasi protein selama pemanasan (Swastawati et al., 2012). Protein yang terdenaturasi akan mengalami koagulasi apabila dipanaskan pada suhu $50^{\circ} \mathrm{C}$ atau lebih (Ghozali et al., 2004).

\section{Kadar Lemak}

Lemak merupakan bagian dari kandungan ikan yang memiliki nilai lebih sedikit dibandingkan dengan protein. Akan tetapi lemak merupakan faktor pendukung dalam menghasilkan rasa dan aroma pada ikan asap. Kadar lemak dalam ikan lele dan patin asap yang diasapi menggunakan smoking cabinet dan tungku pada tabel 1, memiliki perbedaan yang sangat nyata $(P<0,01)$. Pengasapan panas, dapat mempengaruhi perubahan nilai kadar lemak, dalam hal ini, lemak pada ikan asap dengan menggunakan smoking 
Karakteristik Kualitas Ikan Asap ...

Tabel 3. Kandungan senyawa Benzo ( $\alpha$ ) Pyrene pada ikan asap

\begin{tabular}{cccc}
\hline No. & Jenis Ikan & SC (ppm) & $\operatorname{Tr}(\mathrm{ppm})$ \\
\hline 1 & Lele (L) & 6,34 & 8,25 \\
2 & Patin (P) & 0,26 & 0,09 \\
\hline
\end{tabular}

Tabel 4. Kandungan phenol, formaldehid, dan asam organik dalam ikan asap yang diolah menggunakan smoking cabinet dan tungku

\begin{tabular}{llllrrrr}
\hline \multirow{2}{*}{ No } & \multirow{2}{*}{ Ikan } & \multicolumn{2}{c}{ Asam organik } & \multicolumn{2}{c}{ Phenol } & \multicolumn{2}{c}{ Formaldehid } \\
\cline { 2 - 8 } & Lele & \multicolumn{1}{c}{ SC } & Tr & SC & \multicolumn{1}{c}{ Sr } & Tr \\
\hline 1 & Lel24 & $0,0,003$ & $0,25 \pm 0,003$ & $0,18 \pm 0,002$ & $0,19 \pm 0,0005$ & $26,92 \pm 0,92$ & $12,53 \pm 1,18$ \\
2 & Patin & $0,49 \pm 0,000$ & $0,32 \pm 0,004$ & $0,13 \pm 0,0005$ & $0,14 \pm 0,0005$ & ND & ND \\
\hline
\end{tabular}

Ket: Rerata dua kali ulangan \pm standar deviasi

ND : Not detected

SC : Smoking cabinet

cabinet, sebagian besar lebih tinggi dibandingkan dengan tungku. Hal ini disebabkan oleh jarak sumber panas dengan ikan yang berbeda. Jarak antara sumber panas dengan ikan pada tungku sangat dekat, sehingga diindikasikan lemak pada ikan mengalami kerusakan. Semakin tinggi suhu dan lama pengasapan, menyebabkan penurunan nilai kadar lemak. Hasil penelitian menunujkkan bahwa kadar lemak ikan bandeng asap dengan lama pengasapan 3 dan 5 jam sebesar 3,53\%; 3,56\% (Swastawati, 2004). Berbeda dengan smoking cabinet, meskipun menggunakan metode pengasapan panas, jarak antara sumber panas dengan ikan tidak dekat, maka kerusakan lemak akibat panas dapat dikurangi. Perubahan kadar lemak dalam ikan selain dipengaruhi oleh suhu, dapat dipengaruhi oleh perbedaan jenis ikan.

Hasil penelitian dari Tamaela (2003), perbedaan jenis ikan memberikan nilai kadar lemak yang berbeda. Ikan cakalang yang diasapi menggunakan pengasapan panas, memiliki kadar lemak sebesar 6,50\%; 5,81\%; 4,39\%; 4,01\%. Selama proses pengasapan, kadar lemak menurun seiring terjadi pengurangan kadar air, karena sebagian lemak dalam tubuh ikan ikut mengalami driploss.

\section{Kadar Air}

Air merupakan kandungan yang terbesar dalam ikan. Air merupakan sarana mikroorganisme untuk berkembang. Sehingga, proses pengasapan, memiliki tujuan untuk menghilangkan kadar air dalam ikan, dan diharapkan dapat memperpanjang umur simpan ikan asap.

Tabel 1 menunjukkan bahwa perbedaan metode pengasapan dan jenis ikan memberikan perbedaan yang sangat nyata $(P<0,01)$ terhadap nilai kadar air. Secara umum, ikan lele dan patin yang diasap dengan metode smoking cabinet (LSC dan PSC) mengandung kadar air lebih tinggi daripada ikan asap dengan metode tungku tradisional ( $\mathrm{LTr}$ dan PTr). Berdasarkan penelitian dari Gonulalan et al., (2003), nilai kadar air dalam pengasapan lidah asap menggunakan asap cair dan tradisional tidak berbeda nyata $(P>0,05)$, Dengan nilai masing-masing $59,58 \%$ dan $59,41 \%$.

Standar nilai kadar air ikan asap berdasarkan SNI adalah maksimal 60\%. Produk ikan asap menggunakan smoking cabinet dan tungku memiliki kadar air masih melebihi batas standar yang telah ditentukan oleh SNI. Tingginya kadar air, disebabkan oleh lama waktu pengasapan yang relatif pendek dan suhu pengasapan yang fluktuatif, menyebabkan proses penguapan air menjadi tidak stabil dan menyebabkan nilai kadar air masih tinggi. Menurut Winarno et al., (1980) dalam Saleh et al., (1995), terjadinya penurunan kadar air akibat penguapan dari produk karena pengaruh suhu udara dan kelembaban lingkungan sekitar. Tingginya kadar air dalam ikan asap yang diolah menggunakan smoking cabinet dan tungku, dapat mempengaruhi kualitas ikan asap yang dihasilkan.

\section{Kadar abu}

Kadar abu merupakan parameter nilai gizi suatu bahan produk yang dihasilkan oleh komponen zat anorganik yang terdapat dalam ikan. Berdasarkan hasil dari pengujian sampel, dapat disimpulkan bahwa perbedaan metode pengasapan menggunakan smoking cabinet dengan tungku dan jenis ikan yang berbeda, pada tabel 1 memberikan perbedaan yang sangat nyata $(P<0,01)$ terhadap nilai kadar abu.

Perbedaan nilai kadar abu, disebabkan oleh lama waktu pengasapan, serta jenis ikan yang digunakan. Hasil penelitian Saleh et al., (1995), kadar abu ikan bandeng segar adalah $1,38 \%$ dan setelah mengalami proses pengasapan menjadi 2,68\%. Sedangkan hasil penelitian dari Daramola et al., (2007), ikan nila asap memiliki kada abu sebesar 9,41\% lebih tinggi dibandingkan nilai kadar abu ikan nila segar sebesar 7,60\%. Kenaikan ini menurut Kanoni (1991), terjadi karena pengendapan unsur-unsur mineral yang terdapat dalam garam saat proses perendaman dalam larutan garam. Unsur-unsur yang terdapat dalam mineral adalah fosfor, kalsium, potassium, sodium, magnesium, belerang, dan klorin.

Kadar abu merupakan parameter nilai gizi bahan makanan. Abu adalah zat anorganik yang dihasilkan dari sisa pembakaran suatu bahan organik. Sebagian besar bahan makanan, yaitu sekitar $96 \%$ terdiri dari bahan organik dan air. Sisanya terdiri dari unsur-unsur mineral. Di dalam tubuh, unsur-unsur mineral berperan dalam zat pembangun dan pengatur. Menurut Sudarmadji et al., (2003), kadar abu berhubungan dengan mineral suatu bahan. Mineral yang terdapat dalam bahan dapat merupakan dua macam garam, yaitu garam organik dan anorganik. Komponen mineral dalam bahan dapat ditentukan jumlahnya dengan cara menentukan sisa-sisa pembakaran garam mineral tersebut, yang dikenal dengan pengabuan.

Nilai $\mathrm{pH}$

Nilai $\mathrm{pH}$ merupakan salah satu indikator dari kualitas 
ikan asap, yang dapat mempengaruhi kadar protein, phenol, formaldehid dan asam organik. Adapun nilai $\mathrm{pH}$ ikan asap dari berbagai macam jenis ikan yang diolah menggunakan smoking cabinet dan tungku tradisional, dapat dilihat pada Tabel 2.

Tabel 2 menunjukkan bahwa nilai pH ikan asap dari dua jenis ikan dan metode pengasapan menggunakan smoking cabinet dan tungku dibawah $\mathrm{pH}$ netral, sehingga dapat disimpulkan bahwa ikan asap tersebut mengandung asam. Hal ini disebabkan oleh jenis bahan bakar yang digunakan adalah tempurung kelapa. berdasarkan dari penelitian Darmadji (1996), kandungan asap dari tempurung kelapa meliputi phenol 3,13\%; karbonil 9,30; pH 3,2; asam asetat 9,2 . Kandungan $\mathrm{pH}$ yang rendah, dapat menyebabkan penurunan $\mathrm{pH}$ ikan asap.

Asap dari tempurung kelapa, mampu menurunkan nilai $\mathrm{pH}$ dari berbagai jenis ikan yang diasapi baik menggunakan smoking cabinet dan tungku. Nilai pH yang terendah adalah ikan patin asap yang menggunakan smoking cabinet. Nilai $\mathrm{pH}$ yang rendah, dapat mempengaruhi kualitas ikan asap yang dihasilkan. Hasil penelitian dari Suprayitno et al., (2000), perbedaan nilai $\mathrm{pH}$ ikan sidat asap berkaitan dengan kandungan asam yang terdapat dalam asap. Kondensat asap kayu akasia memiliki asam-asam organik paling rendah yaitu $23,48 \%$. Kandungan asam yang tinggi akan menyebabkan nilai pH ikan asap menurun.

Gonulalan et al., (2003) meneliti, selama penyimpanan, nilai $\mathrm{pH}$ daging kalkun yang diasapi dengan asap cair mengalami penurunan yaitu, 6,36 (hari ke-0); 6,24 (hari ke-5); 6,15 (hari ke-10); 6,18 (hari ke-15); 6,10 (hari ke 30). Perbedaan $\mathrm{pH}$ terjadi akibat tingkat atau aktivitas dari bakteri asam laktat dan jumlah dari asam-asam organik dalam asap cair.

Hal ini didukung dengan hasil penelitian dari Martinez et al., (2005), nilai pH ikan Salmon asap yang disimpan dengan suhu $2^{\circ} \mathrm{C}$ selama 45 hari mengalami penurunan, mulai 6,12 sampai 5,64. Hassan (1988) dalam Martinez et al., (2005) menjelaskan bahwa, pengasapan menyebabkan penurunan $\mathrm{pH}$, akibat dari penyerapan komponen asamasam yang terdapat dalam asap cair. Reaksi antara phenol, polyphenol dan komponen karbonil dengan protein menyebabkan kehilangan kadar air sehingga menurunkan $\mathrm{pH}$ ikan asap.

\section{Benzo ( $\alpha$ ) Pyrene}

Senyawa Polycyclic Aromatic Hydrocarbons (PAHs) merupakan senyawa karsinogenik yang umumnya terdapat di produk yang menggunakan suhu tinggi, khususnya pada produk ikan asap. Salah satu komponen PAHs yang berperan dalam karsinogenik adalah Benzo ( $\alpha$ ) Pyrene. Adapun kandungan senyawa Benzo ( $\alpha)$ Pyrene dapat dilihat pada tabel 3.

Berdasarkan Tabel 3 diatas, kandungan Benzo $(\alpha)$ Pyrene pada ikan asap dengan menggunakan tungku atau secara tradisional, memiliki perbedaan yang sangat nyata $(P<0,01)$, serta, kadar Benzo $(\alpha)$ Pyrene antar sampel atau jenis ikan memiliki perbedaan yang sangat nyata $(P<0,01)$. Nilai kandungan Benzo ( $\alpha$ ) Pyrene pada ikan asap dengan tungku sebagian besar lebih tinggi dibandingkan menggunakan smoking cabinet.

Pengaruh tingginya kandungan Benzo ( $\alpha$ ) Pyrene, antara lain disebabkan oleh panas yang kurang terkontrol di pengasapan menggunakan tungku. Pada metoda smoking cabinet, jarak ikan dan api dapat diatur dan suhu dapat dikontrol, sehingga kandungan Benzo $(\alpha)$ Pyrene yang terdapat pada ikan asap dapat diminimalkan.

Berdasarkan penelitian Hadiwiyoto et al., (2000), metoda pengasapan panas atau secara tradisional, menyebabkan kandungan Benzo ( $\alpha$ ) Pyrene lebih tinggi. Ikan kakap menggunakan pengasapan panas dan liquid smoke kandungan Benzo ( $\alpha$ ) Pyrene sebesar 0,52 ppb; 0,3 ppb; ikan tenggiri 0,58 ppb; 0,32 ppb; dan ikan tongkol 0,63 ppb; 0,34 ppb. Hasil penelitian dari Swastawati (2008), Benzo $(\alpha)$ Pyrene diindikasikan sebagai senyawa karsinogenik yang menjadi kekhawatiran masyarakat saat ini. Ikan manyung asap yang diolah menggunakan asap cair sekam padi mengandung Benzo ( $\alpha$ ) Pyrene sebesar 0,541 ppm; dengan asap cair tempurung kelapa mengandung Benzo ( $\alpha$ ) Pyrene sebesar 48,254 ppm.

Berdasarkan peraturan yang diterbitkan oleh The European Parliament and of The Council nomor No 2065/2003 (2003), menetapkan bahwa batas maksimal kandungan Benzo ( $\alpha$ ) Pyrene dalam ikan asap sebesar 1 ppb. Dapat disimpulkan bahwa, kandungan Benzo $(\alpha)$ Pyrene ikan asap baik dengan metode SC dan Tr, masih diatas ambang batas yang telah ditetapkan oleh pemerintah Eropa. Akan tetapi, nilai Benzo $(\alpha)$ Pyrene dari ikan asap dengan kedua metode tersebut, masih dapat diminimalkan dengan proses pengasapan yang baik dan benar.

Benzo $(\alpha)$ Pyrene hasil dari pembakaran bahan-bahan organik yang kurang sempurna khususnya dalam pengasapan ikan secara sederhana. Mekanisme Benzo ( $\alpha)$ Pyrene dapat mengakibatkan karsinogenik. Hal ini dikarenakan sifat dari Benzo ( $\alpha$ ) Pyrene yang hidrofobik (tidak suka akan air), dan tidak memiliki gugusmetil atau gugus reaktif lainnya untuk dapat diubah menjadi senyawa yang lebih polar. Akibatnya senyawa PAH sangat sulit diekskresi dari dalam tubuh dan biasanya terakumulasi pada jaringan hati, ginjal, maupun adiposa atau lemak tubuh. Dengan struktur molekul yang menyerupai basa nukleat (adenosin, timin, guanin, dan sitosin), molekul PAH dapat dengan mudah menyisipkan diri pada untaian DNA. Akibatnya fungsi DNA akan terganggu dan apabila kerusakan ini tidak dapat diperbaiki dalam sel, maka akan menimbulkan penyakit kanker (Varlet et al., 2007; Elisabeth, et al., 2000).

Phenol, formaldehid, dan asam organik

Asap adalah hasil pembakaran kayu tidak sempurna yang mengandung aldehid, keton, phenol, formaldehid, asam organik yang berperan dalam antioksidan, antibakteri, pembentuk warna, rasa, dan aroma yang khas (Goulas et al., 2005). Kandungan phenol, formaldehid, dan asam organik pada ikan asap dari berbagai jenis ikan dan metode yang berbeda, dapat dilihat dalam Tabel 4.

Berdasarkan Tabel 4 diatas, kandungan formaldehid organik pada ikan asap yang diolah menggunakan metode pengasapan smoking cabinet dan tungku, tidak berbeda nyata $(P>0,05)$, akan tetapi, ikan asap dengan jenis ikan yang 
Karakteristik Kualitas Ikan Asap ...

berbeda dan metode pengasapan yang berbeda memberikan perbedaan yang sangat nyata terhadap kandungan phenol dan asam organik. Hal ini disebabkan oleh kandungan selulosa pada tempurung kelapa yang bervariasi. Menurut Darmadji (1996), kadar phenol dalam asap sangat bervariasi tergantung pada jenis kayu sebagai bahan bakar. Kandungan selulosa yang tinggi maka akan tinggi pula senyawa karbonil, sebab perlakuan pemanasan suhu tinggi akan menghasilkan karbonil. Kandungan asap dari tempurung kelapa meliputi phenol 3,13\%; karbonil 9,30; $\mathrm{pH} 3,2$; asam asetat 9,2.

Variasi dari kadar phenol dalam asap memberikan pengaruh terhadap kandungan phenol dalam ikan. Berdasarkan penelitian Birkerland et al., (2005), peningkatan kadar phenol, terjadi akibat adanya suhu dan lama pemanasan, semakin tinggi suhu dan waktu pengasapan maka akan tinggi pula phenol yang dihasilkan. Nilai phenol dari ikan salmon asap adalah 0,76; 0,82 mg/100g sampel. Phenol berperan penting dalam kualitas ikan asap yang dihasilkan. Selain phenol, terdapat komponen lain yaitu formaldehid.

Kandungan formaldehid dalam ikan asap menggunakan smoking cabinet dan tungku, tidak memiliki perbedaan yang nyata $(P>0,05)$. Formaldehid dalam ikan asap menggunakan smoking cabinet sebagian tidak terdeteksi, hal ini disebabkan karena pengaturan suhu yang kurang terkontrol, menyebabkan penyerapan formaldehid ke dalam ikan menjadi tidak stabil. Kandungan ikan asap yang mampu mempengaruhi kualitas selain phenol dan formaldehid adalah asam organik.

Ikan asap menggunakan smoking cabinet dan tungku tidak memberikan perbedaan yang nyata $(P>0,05)$ terhadap nilai asam organik. Hal ini disebabkan karena bahan bakar yang digunakan adalah sama-sama menggunakan tempurung kelapa. Kandungan asam organik yang paling tinggi adalah ikan patin asap menggunakan smoking cabinet (Tabel 4). Asam oganik berserta phenol dan formaldehid, berperan dalam kualitas ikan asap, membentuk warna ikan asap menjadi coklat keemasan, aroma khas ikan asap, antibakteri, dan antioksidan.

Menurut Darmadji (1996), keasaman mempunyai peranan yang besar dalam penghambatan mikrobia. Pada $\mathrm{pH}$ 4, asap cair mampu menghambat pertumbuhan mikrobia. Asap cair tempurung kelapa dengan pengenceran 10x mampu menghambat pertumbuhan bakteri selama 16 jam pada suhu $30^{\circ} \mathrm{C}$.

\section{KESIMPULAN DAN SARAN}

Pengasapan ikan dengan smoking cabinet dan tungku tradisional dapat diterapkan sebagai metoda pengolahan ikan asap dan dapat menghasilkan kualitas ikan asap yang baik secara organoleptik, dan kandungan nutrisi terjaga. Serta dapat dijadikan sebagai metode alternatif untuk mengurangi bahaya karsinogenik pada ikan asap, mengingat ikan asap yang dihasilkan dari smoking cabinet dan tungku, memiliki nilai Benzo ( $\alpha$ ) Pyrene yang masih dapat diterima dan aman untuk dikonsumsi. Ikan lele dan patin, memiliki potensi sebagai bahan baku ikan asap yang memiliki kandungan proksimat yang tinggi, sehingga mampu memenuhi kebutuhan gizi masyarakat.

\section{DAFTAR PUSTAKA}

Association of Official Analytical Chemists (AOAC). 1990. Official Methods of Analysis $18^{\text {th }}$ Edition. Benyamin Franklin. Washington DC. USA.

Birkerland, Sveinung., Anna Maria Bencze Rora., Torstein Skera., Bjorn Bjerkeng. 2004. Effect of Cold Smoking Procedures and Raw Material Characteristics on Product Yield and Quality Parameters of Cold Smoked Atlantic Salmon (Salmo salar L.) Fillets. Food Research International 37: $273-286$.

Cardinal, M., Cornet, J., Serot, T., Baron, R. 2006. Effects of the Smoking Process on Odour Characteristics of Smoked Herring (Clupea harengus) and Relationship with Phenolic Compound Content. Food Chemistry: $137-146$.

Daramola, J. A. , Fasakin, E. A., dan Adeparusi, E. O. 2007. Cahnges in Physicochemical and Sensory Characteristics of Smoke-Dried Fish Species Stored at Ambient Temperature. African Journal of Food Agriculture Nutrition Development. Volume 7 No. 6, December 2007.

Darmadji, P. 1996. Aktivitas Antibakteri Asap Cair yang Diproduksi dari Bermacam-macam Limbah Pertanian. Jurnal Agritech Vol. 16 No. 4. Universitas Gajah Mada. Yogyakarta: 19-22.

Ekpenyoung, E., C. O. Ibok. 2012. Effect of Smoking, Salting and Frozen-Storage on the Nutrient Composition of the African Catfish (Clarias gariepinus). Journal of Food, Agriculture and Environment Vol 10 (1): 64 66.

Elisabeth, J., T Haryati, Donald S. 2000. Polycyclic Aromatic Hydrocarbon (PAH) : Kaitannya dengan Minyak Sawit dan Kesehatan, dalam Warta PPKS (Pusat Penelitian Kelapa Sawit), Medan.

Gonulalan, Z., A. Kose., H. Yetim. 2003. Effects of Liquid smoke on Quality Characteristics of Turkish Standard Smoked Beef Tongue. Meat Science. Turkey: 165-170.

Goulas, Antonios E., Michael G. Kontominas. 2005. Effect of Salting and Smoking Method on the Keeping Quality of Chub Mackerel (Scomber japonicus): Biochemical and Sensory Atributes. Food Chemistry 93: 511 - 520.

Ghozali, Thomas., Dedi Muchtadi., Yaroh. 2004. Peningkatan Daya Tahan Simpan Sate Bandeng (Chanos chanos) dengan Cara Penyimpanan Dingin dan Pembekuan. Infomatek, Vol. 6 Nomor 1. Bandung.

Hadiwiyoto, Suwedo., Sri Naruki., Sri Satyanti., Hastini Rahayu., dan Diana Riptakasari. 2000. Perubahan Kelarutan Protein, Kandungan Lisin (Available), Metionin, dan Histidin Bandeng Presto Selama Penyimpanan dan Pemasakan Ulang. Agritech Vol. 19. No. 2. Universitas Gajahmada. Yogyakarta: 78-82.

Kanoni, Sri. 1991. Kimia dan Teknologi Pengolahan Ikan. Pusat Antar Universitas Pangan dan Gizi. Universitas Gajahmada. Yogyakarta.

Martinez, O. 2005. Textural and Physicochemicial Changes in Salmon (Salmo salar) Treated with Commercial Liquid Smoke Flavourings. http://www. Elsevier.com: 498503.

Sudarmaji, S., B. Hariyono., dan Suhardi. 2003. Analisa 
Bahan Makanan dan Pertanian. Liberty. Yogyakarta. $171 \mathrm{hlm}$.

Saleh, M., Irwandi., F. G. Winarno., dan Y. Haryadi. 1995. Pengaruh Perlakuan Larutan Perendam terhadap Kadar Urea Daging Cucut Segar dan Mutu Daging Asapnya. Jurnal Penelitian Perikanan Indonesia 1 (3).

SNI. 2006. Pengujian Kadar Abu pada Produk Perikanan. SNI No. 01-2354.1.2006. Badan Standarisasi Nasional.

SNI. 2006. Pengujian Kadar Air pada Produk Perikanan. SNI No. 01-2354.2.2006. Badan Standarisasi Nasional.

SNI. 2006. Pengujian Kadar Lemak pada Produk Perikanan. SNI No. 01-2354.3.2006. Badan Standarisasi Nasional.

SNI. 2006. Pengujian Kadar Protein pada Produk Perikanan. SNI No. 01-2354.4.2006. Badan Standarisasi Nasional.

SNI. 2009. Penilaian Organoleptik pada Produk Ikan Asap. SNI No. 01-2725.1.2009. Badan Standarisasi Nasional.

SNI. 2006. Pengujian Kadar Abu pada Produk Perikanan. SNI No. 01-2354.1.2006. Badan Standarisasi Nasional.

Suprayitno, Eddy., T. J. Moejiharto, dan Wahyu Prasetya. 2000. Kualitas Ikan Sidat (Anguilla bicolor) Asap dengan Presentase Garam dan Kayu Penghasil Asap yang Berbeda. Jurnal Makanan Tradisonal Indonesia: 41-45.

Swastawati, Fronthea. 2004. The Effect of Smoking duration on the Quality and DHA Composition of Milkfish (Chanos chanos F). Journal of Coastal Development,
Vol. 7 Number 3, May 2004: 137-142.

Swastawati, Fronthea., Tri Winarni Agustini., Y. S. Darmanto., Eko Nurcahya Dewi. 2007. Liquid Smoke Performance of Lamtoro Wood and Corn Cob. Journal of Coastal Development, Vol. 10, Number 3, June 2007: 189-196

Swastawati, Fronthea. 2008. Quality and Safety of Smoked Catfish (Arius talassinus) Using Paddy Chaff and Coconut Shell Liquid Smoke. Journal of Coastal Development Vol. 12 No. 1, October 2008: 47-55.

Swastawati, Fronthea., Eko Susanto., Bambang Cahyono., Wahyu Aji Trilaksono. 2012. Sensory Evaluation and Chemical Characteristics of Smoked Stingray (Dasyatis blekeery) Processed by Using Two Different Liquid Smoke. International Journal of Bioscience, Biochemistry and Bioinformatics Vol. 2 No. 3: $212-$ 216.

Tamaela, P. 2003. Efek Antioksidan Asap Cair Tempurung Kelapa untuk Menghambat Oksidasi Lipida pada Steak Ikan Cakalang (Katsuwonus pelamis) Asap Selama Penyimpanan. Ichtyos, Vol. 2, No. 2, Juli 2003: 59-62.

The European parliament and of the council. 2003. Regulation (ec) No 2065/2003 on Smoke Flavourings Used or Intended for Use in or on Foods. Official journal of the European Union. 